\title{
İhale Usulü ve Sözleşme Türünün Yapım İşi Sözleșme Bedeline Etkisinin İncelenmesi
}

\author{
Ezgi KOCAMAN ${ }^{1}$ \\ Merve KURU ${ }^{2}$ \\ Gülben ÇALIŞ ${ }^{3}$
}

\section{ÖZ}

Bu çalışmanın amacı (1) sözleşme bedeli ve ihale usulü; (2) sözleşme bedeli ve ihale eşik değer durumu; (3) sözleşme bedeli ve sözleşme türü; (4) sözleşme bedeli/yaklaşık maliyet oranı ve ihale usulü arasındaki ilişkinin araştırılmasıdır. Bu kapsamda, 2007 ve 2017 yılları arasında yaklaşık 169.9 milyon USD tutarlı açık ihale usulü, yaklaşık 25.9 milyon USD tutarlı belli istekliler arasında ihale usulü, yaklaşık 25.6 milyon USD tutarlı pazarlık usulü olarak gerçekleştirilen toplam 219.546 adet yapım işi ihale verisi analiz edilmiştir. Sonuçlar, ihale usulü, ihale eşik değer durumu ve sözleşme türünün sözleşme bedelleri üzerinde istatistiksel olarak anlamlı etkisi olduğunu göstermektedir. Ayrıca, pazarlık usulü, sözleşme bedeli/yaklaşık maliyet oranında istatistiksel olarak farka neden olmaktadır.

Anahtar Kelimeler: Yapım işi, sözleşme bedeli, yaklaşık maliyet, ihale usulü, sözleşme türü.

\section{ABSTRACT \\ Investigating the Effect of Tendering Procedure and Contract Type on the Construction Contract Price}

This study aims at investigating the relationship between (1) contract price and tendering procedure (2) contract price and threshold value (3) contract price and contract type (4) contract price/approximate cost ratio and tendering procedure. Within this context, a total of 219.546 tender procedures of construction work data between the years 2007 and 2017, which involves open tender procedures worth approximately 169.9 million USD, restricted

\footnotetext{
Not: Bu yaz1

- Yayın Kurulu’na 7 Eylül 2018 günü ulaşmıştır. 18 Mart 2019 günü yayımlanmak üzere kabul edilmiştir.

- 31 Mart 2020 gününe kadar tartışmaya açıktır.

- https://doi.org/10.18400/tekderg.458054

1 Ege Üniversitesi, İnşaat Mühendisliği Bölümü, İzmir - ezgkcmn@gmail.com https://orcid.org/0000-0002-1013-0904

2 Ege Üniversitesi, İnşaat Mühendisliği Bölümü, İzmir - mervekuru25@gmail.com https://orcid.org/0000-0002-2698-6491

3 Ege Üniversitesi, İnşaat Mühendisliği Bölümü, İzmir - gulben.calis@ege.edu.tr https://orcid.org/0000-0003-3056-4870
} 
tender procedures worth 25.9 million USD, negotiated tender procedures worth approximately 25.6 USD, were analyzed The results show that tendering procedure, threshold value and the contract type have a statistically significant effect on the contract prices. In addition, negotiated tender procedure causes a statistical significance on the contract price/approximate cost ratio.

Keywords: Construction work, contract price, approximate cost, tendering procedure, contract type.

\section{GíRiş}

Kamu ihtiyaçlarının en iyi şekilde, uygun şartlarla zamanında karşılanması ve ihalede açıklık ve rekabet koşullarının sağlanması Türk kamu ihale sisteminin temelini oluşturmaktadır. 2002 yılında yürürlüğe giren 4734 sayılı Kamu İhale Kanunu ile kanunda belirtilen görevleri yapmak üzere, kamu tüzel kişiliğine haiz, idari ve malî özerkliğe sahip Kamu İhale Kurumu (KİK) oluşturulmuştur. Böylece kamu ihalelerindeki uygulamaları yönlendirecek, şikâyetleri çözüme bağlayacak, hukuken ve idari olarak bağımsız ve tarafsız bir kurum oluşturulmuş olmaktadır. 4734 sayılı Kamu İhale Kanunu madde 2 gereğince Kanunda belirtilen idarelerin kullanımında bulunan her türlü kaynaktan karşılanan mal veya hizmet alımları ile yapım işlerinin ihaleleri bu Kanun hükümlerine göre yürütülür. Mal alımı satın alınan her türlü ihtiyaç maddeleri ile taşınır ve taşınmaz mal ve haklarını; hizmet alımı ise taşınır ve taşınmaz mal ve hakların kiralanması ve benzeri diğer hizmetlerini ifade etmektedir. Yapım işi bina, karayolu, demiryolu, otoyol, liman, baraj, alt yapı ve benzeri yapım işlerini ifade etmektedir.

4734 sayılı Kamu İhale Kanunu madde 18 idarelerce mal veya hizmet alımları ile yapım işlerinin ihalelerinde açık ihale, belli istekliler arasında ve pazarlık usullerden birinin uygulanacağını belirtir. Açık ihale usulü bütün isteklilerin teklif verebildiği; belli istekliler arasında ihale usulü ön yeterlilik değerlendirmesi sonucunda idare tarafından davet edilen isteklilerin teklif verebildiği; pazarlık usulü ise idarenin ihale konusu işin teknik detayları ile gerçekleştirme yöntemlerini ve belli hallerde fiyatı isteklilerle görüştüğü usuldür.

4735 sayılı Kamu İhale Sözleşmeleri Kanunu 6. Maddesi ihaleler sonucunda yapılacak sözleşme türlerini tanımlanmaktadır. Anahtar teslimi götürü bedel sözleşme yapım işlerinde işin tamamı için isteklinin teklif ettiği toplam bedel üzerinden düzenlenen; götürü bedel sözleşme mal veya hizmet alımı işlerinde işin tamamı için isteklinin teklif ettiği toplam bedel üzerinden düzenlenen; birim fiyat sözleşme yapım işlerinde her bir iş kaleminin miktarı ile bu iş kalemleri için istekli tarafından teklif edilen birim fiyatların çarpımı sonucu bulunan toplam bedel üzerinden düzenlenen; karma sözleşme ise yapım işlerinde iş kalemlerinin bir kısmı için anahtar teslimi götürü bedel, bir kısmı için birim fiyat teklifi alma yöntemleri ile gerçekleştirilen ihaleler sonucunda düzenlenen sözleşmelerdir. Sözleşme türünün seçimi proje riskleri açısından önem taşımaktadır. Götürü bedelli sözleşmeler ve birim fiyatlı sözleşmelerin mal sahibi (idare) ve yüklenici firma açısından risklerin dağılımı Çizelge 1'de verilmektedir.

Türkiye gibi gelişmekte olan ülkelerde bireylerin ihtiyaçları değişism ve gelişim göstermektedir. Kamu kurumlarının da ihtiyaçları tıpkı bireyler gibi değişmekte ve gelişmektedir. $\mathrm{Bu}$ değişim ve gelişim sonucunda kamu hizmetlerinde meydana gelen 
Çizelge 1 - Sözleşme türlerindeki risklerin dă̆ılımı [1]

\begin{tabular}{|c|c|c|}
\hline & \\
\hline & Götürü Bedelli & Birim Fiyat \\
\hline & Sözleşmeler & Sözleşmeler \\
\hline $\begin{array}{l}\text { Projelerin ihale } \\
\text { aşamasında }\end{array}$ & $\begin{array}{l}\text { İhale aşamasından önce } \\
\text { tasarım ve detayların } \\
\text { hazırlanması gereklidir. }\end{array}$ & $\begin{array}{l}\text { İşin özelliği değişmemek } \\
\text { kaydıyla tüm detayların hazır } \\
\text { olması gerekmeyebilir. }\end{array}$ \\
\hline $\begin{array}{l}\text { Proje değişikliği } \\
\text { nedeniyle } \\
\text { keşif artışında } \\
\text { esneklik }\end{array}$ & Çok kisitlı & $\begin{array}{l}\text { Belirli bir oranda iş artışı veya } \\
\text { eksilişi olabilir. }\end{array}$ \\
\hline $\begin{array}{l}\text { Önerilen değişiklik } \\
\text { nedeniyle } \\
\text { çlkabilecek } \\
\text { anlaşmazlıklar }\end{array}$ & $\begin{array}{l}\text { Değişikliklerden } \\
\text { kaynaklanan anlaşmazlık } \\
\text { olasılığı yüksektir. }\end{array}$ & $\begin{array}{l}\text { Değişiklikler sözleşmede } \\
\text { belirlenen fiyatları } \\
\text { kapsayacağından, } \\
\text { değişikliklerden kaynaklanan } \\
\text { anlaşmazlık olasılığı } \\
\text { genellikle düşüktür. }\end{array}$ \\
\hline Toplam maliyet & $\begin{array}{l}\text { Önceden belirlenmiştir. } \\
\text { Maliyetin önceden } \\
\text { belirlenmiş olması işveren } \\
\text { için bir avantajidır. }\end{array}$ & $\begin{array}{l}\text { Maliyet iş artış veya eksilişine } \\
\text { göre değişiklik gösterebilir. }\end{array}$ \\
\hline $\begin{array}{l}\text { Yüklenicinin riskler } \\
\text { için yaptı̆̆ } \\
\text { düzenleme }\end{array}$ & $\begin{array}{l}\text { İhale öncesinde teklif } \\
\text { hazırlanırken olası riskler } \\
\text { göz önünde bulundurulmalı } \\
\text { ve maliyete bir risk } \\
\text { toleransı dahil edilmelidir. }\end{array}$ & $\begin{array}{l}\text { Yüklenici olası riskleri göz } \\
\text { önünde bulundurmalıdır. } \\
\text { Bununla birlikte olası fiyat } \\
\text { artışlarını talep edebilir. }\end{array}$ \\
\hline İşin süresi & $\begin{array}{l}\text { Yüklenici en kisa sürede } \\
\text { işini bitirmeyi amaçlar. } \\
\text { Sürenin uzaması işin } \\
\text { yönetimi için bir risktir. }\end{array}$ & $\begin{array}{l}\text { Yükleniciden kaynaklanan bir } \\
\text { süre uzaması durumunda, } \\
\text { yüklenici cezai şartlara tabi } \\
\text { olacağından işi belirtilen } \\
\text { sürede bitirmeyi amaçlar. İşin } \\
\text { süresinin uzaması finansal } \\
\text { risklere yol açabilir. }\end{array}$ \\
\hline İşveren denetimi & $\begin{array}{l}\text { Belirli bir kalite } \\
\text { standardının sağlanması } \\
\text { açısından sürekli ve ciddi } \\
\text { bir denetim gereklidir. }\end{array}$ & $\begin{array}{l}\text { Yapılan işin sözleşme ve } \\
\text { ekleri ile fen ve sanat } \\
\text { kurallarına uygunluğunun } \\
\text { denetimi gereklidir. }\end{array}$ \\
\hline
\end{tabular}

genişlemeye bağlı olarak kamu alımlarının gayri safi yurtiçi hasıladan (GSYH) aldığı pay artmaktadır. Kamu alımlarının ekonomideki bu öneminden ötürü kamu kaynaklarının etkin ve verimli kullanılması gerekmektedir. Buna paralel olarak yapım işi ihaleleri de yıldan yıla artış göstermektedir. Yapım işi ihalelerinde kamu kaynağı ihtiyacının belirlenmesinde temel 
faktör, önceden planlanan yapım işine ilişkin, idareler tarafından her türlü fiyat araştırması yapılarak ve katma değer vergisi (KDV) hariç tutularak belirlenen tahmini maliyet olan yaklaşık maliyettir (YM). İdarelerce gerçekleştirilen yapım işlerine ait YM belirleme yöntemi, başta T.C. Çevre ve Şehircilik Bakanlığı olmak üzere birim fiyat belirleme görev ve yetkisi bulunan diğer kamu kurumları tarafından belirlenen kamu birim fiyat sistemine dayanmaktadır [2]. Ayrıca, idareler yatırımın henüz uygulama projeleri hazırlamadan yatırım programına alınması aşamasında bütçeye ödenek konulabilmesi için parametrik yöntem kullanmaktadır. Bu yöntem, proje maliyetlerini hesaplayabilmek ve tahmin edebilmek için proje özelliklerini bir matematik modelde kullanmayı içermektedir [3]. Kanıt ve Baykan [4] kamuya ait bina yatırımları arasında sağlık ocaklarını örnekleyerek bölge, süre, ihale indirimi ve tahmini $\mathrm{m}^{2}$ maliyet parametrelerinin YM ile ilişkisini araştırmak için çoklu doğrusal regresyon analizini kullanmışlardır. Sonuçlar, geçmiş maliyet verileriyle geleceğe yönelik güvenilir tahminler yapılabileceğini göstermiştir. Uğur vd. [5] çalışmalarında, tek katlı bir yığma konut projesi dizayn etmiş ve yapay sinir ağı modelini oluşturarak YM tahmini yapmışlardır. Çalışma sonucunda yapay sinir ağı modeli ile \% 5 'lik hata oranı dahilinde kabul edilebilir maliyet değerleri elde etmişlerdir. Bir başka çalışmada [6], statik ve betonarme analizler ile elde edilen beton, kalıp, ve donatı metraj değerleri yapay sinir ağları ile programlanarak kaba inşaat YM hesaplanmış ve \%98 doğruluk oranı elde edilmişstir. Aksoy [2], YM tespitinde piyasa fiyatlarının esas alınması ya da bölgesel düzeyde birim fiyat tespit edilmesi ve kullanılması gibi alternatif YM tespit yöntemlerinin ekonomik faydalarına dikkat çekmiştir.

Yapım işi kamu alımlarında yaklaşık maliyetin gerçekçi ve doğru hesaplanması kamu kaynaklarının etkin kullanımı ve ihaleye en uygun sözleşme bedelinin (SB) seçilmesi açısından önemlidir. Sözleşme bedeli yaklaşık maliyet oranı (SB/YM) kamunun gerçekleştirilen ihalelerden ne kadar tasarruf ettiğini ve istekliler açısından rekabetin nasıl yaşandığını belirleyen çok önemli bir göstergedir. Bu nedenle literatürde sözleşme bedelinin tahminlenmesi ve ihalelerde rekabetin sağlanması üzerine yapılan çalışmalara rastlanılmaktadır. Elhag vd. [7] ihale öncesi sözleşme bedelinin tahminlemesinde 6 farklı faktörün etkisini araştırmışlardır. Sonuçlar, ihale öncesi sözleşme bedeli tahminini sırasıyla danışman ve tasarım parametreleri, müşteri karakteristiği, proje karakteristiği, diş faktörler ve pazar durumu, sözleşme prosedürleri ve ihale ile ilgili yöntemler ve yüklenici özelliklerinin etkilediğini göstermektedir. Skitmore ve $\mathrm{Ng}$ [8] sözleşme türünün inşaat maliyeti ve sözleşme bedeline etkisini regresyon analizi ile araştırmışlardır. Sonuçlar dizayn, proje ve inşaat aşamaları için ayrı ayrı ihaleye çıkılmasının, proje süresi ve maliyetinin azalmasını sağladığını göstermektedir. Drew vd. [9] sözleşme tipi, sözleşme büyüklüğü ve iş sahibinin türünün (kamu/özel sektör), sözleşme bedeline olan etkisini incelemişlerdir. Sonuçlar sözleşmenin büyüklüğünün, ihale sonucunda ortaya çıkacak sözleşme bedelini en çok etkileyen faktör olduğunu göstermektedir. Ayrıca, ihale öncesi sözleşme bedelinin tahminlenmesine ilişkin yapılan eski çalışmalar Skitmore [10] tarafından özetlenmektedir. Her ne kadar yapılan çalışmalarda sözleşme bedeline bazı faktörlerin etkisi incelenmiş olsa da, sözleşme bedelinin idarelerce 4734 sayılı kanunda belirtilen ihale usullerinden, ihale eşik değer durumundan; 4735 sayılı kanuna göre yapacakları sözleşme türünden ve/veya idarelerce hesaplanan yaklaşık maliyetten etkilenip etkilenmediği konusunda yapılan bir çalışmaya rastlanılmamaktadır. Bu çalışmada (1) sözleşme bedeli ve ihale usulü (2) sözleşme bedeli ve ihale eşik değer durumu (3) sözleşme bedeli ve sözleşme türü (4) sözleşme bedeli yaklaşık maliyet oranı ve ihale usulü arasındaki ilişkinin araştırılması amaçlanmaktadır. $\mathrm{Bu}$ 
kapsamda, 2007-2017 yılları arasında 4734 sayılı kanun kapsamında gerçekleştirilen yapım işlerine ait veriler ihale usulü ve sözleşme türüne göre derlenmiş ve istatistiksel olarak analiz edilmiştir. Bundan sonraki bölümlerde sırasıyla materyal, yöntem, analizler ve sonuçlar sunulmaktadir.

\section{MATERYAL}

KİK tarafından her yıl yayımlanan Kamu Alımları İzleme Raporları'nda, çevrimiçi veri girişine imkân sağlayan Elektronik Kamu Alımları Platformu'na kayıtlı idarelerin yürüttükleri ihalelere ilişkin bilgi ve verileri derlemektedir. Çalışma kapsamında 2007-2017 yılları arasında 4734 sayılı kanun kapsamında gerçekleştirilen yapım işi verileri KİK raporlarından elde edilmiştir [11]. Raporlarda yapım işi ihale adetleri ve Türk Lirası (TL) cinsinden sözleşme bedelleri yer almaktadır. Bu çalışmada, sözleşme bedeline ilişkin veriler, US doları (USD) karşılığı hesaplanarak düzenlenmiştir. USD karşılığı hesaplanırken, ilgili kamu izleme raporunu takip eden yılın ilk iş günündeki Merkez Bankası dolar döviz satış kuru dikkate alınmıştır.

2007-2017 yılları arasında gerçekleştirilen yapım işlerinin adet ve USD karş1lığg sözleşme bedellerinin ihale usullerine göre dağılımı Çizelge 2'de verilmektedir. Çizelge'de adet ve sözleşme bedeli yıl içi yüzde oranları, ihale usullerinin o yıl içerisinde gerçekleşen toplam ihale adedi ve sözleşme bedeline oranını göstermekte olup ilgili yıla ait veriler dikkate alınarak hesaplanmaktadır.

Çizelge 2 - 2007-2017 yılları arasında gerçekleştirilen yapım işlerinin ihale usullerine göre dă̆ılımı

\begin{tabular}{|l|l|c|c|c|c|c|}
\hline \multirow{1}{*}{ Yıllar } & \multicolumn{1}{|c|}{ İhale Usulleri } & Adet & $\begin{array}{c}\text { Adet } \\
\text { Yl İçi } \\
\mathbf{\%}\end{array}$ & $\begin{array}{c}\text { Sözleşme } \\
\text { Bedeli } \\
\text { (USD) }\end{array}$ & $\begin{array}{c}\text { SB } \\
\text { Yıl İçi } \\
\mathbf{\%}\end{array}$ & $\begin{array}{c}\text { Birim } \\
\text { Sözleşme } \\
\text { Bedeli } \\
\text { (USD) }\end{array}$ \\
\hline \multirow{4}{*}{$\mathbf{2 0 0 7}$} & Açık İhale Usulü & 19.765 & 95,49 & 17.928 .802 & 88,41 & 907,1 \\
\cline { 2 - 8 } & $\begin{array}{l}\text { Belli İstekliler } \\
\text { Arasında İhale Usulü }\end{array}$ & 43 & 0,21 & 1.258 .085 & 6,20 & 29257,8 \\
\cline { 2 - 8 } & Pazarlık Usulü & 890 & 4,30 & 1.091 .150 & 5,38 & 1226,0 \\
\cline { 2 - 8 } & Toplam & $\mathbf{2 0 . 6 9 8}$ & $\mathbf{1 0 0 , 0 0}$ & $\mathbf{2 0 . 2 7 8 . 0 3 6}$ & $\mathbf{1 0 0 , 0 0}$ & - \\
\hline \multirow{2}{*}{$\mathbf{2 0 0 8}$} & Açık İhale Usulü & 20.937 & 95,24 & 15.338 .485 & 90,51 & 732,6 \\
\cline { 2 - 8 } & $\begin{array}{l}\text { Belli İstekliler } \\
\text { Arasında İhale Usulü }\end{array}$ & 43 & 0,20 & 749.893 & 4,42 & 17439,4 \\
\cline { 2 - 8 } & Pazarlık Usulü & 1.003 & 4,56 & 858.948 & 5,07 & 856,4 \\
\cline { 2 - 8 } & Toplam & $\mathbf{2 1 . 9 8 3}$ & $\mathbf{1 0 0 , 0 0}$ & $\mathbf{1 6 . 9 4 7 . 3 2 6}$ & $\mathbf{1 0 0 , 0 0}$ & - \\
\hline
\end{tabular}




\begin{tabular}{|c|c|c|c|c|c|c|}
\hline Yillar & İhale Usulleri & Adet & $\begin{array}{c}\text { Adet } \\
\text { Yll İçi } \\
\%\end{array}$ & $\begin{array}{c}\text { Sözleşme } \\
\text { Bedeli } \\
\text { (USD) }\end{array}$ & $\begin{array}{c}\text { SB } \\
\text { Yıl İçi } \\
\%\end{array}$ & $\begin{array}{c}\text { Birim } \\
\text { Sözleşme } \\
\text { Bedeli } \\
\text { (USD) }\end{array}$ \\
\hline \multirow{4}{*}{2009} & Açık İhale Usulü & 16.330 & 94,31 & 11.686 .144 & 87,77 & 715,6 \\
\hline & $\begin{array}{l}\text { Belli İstekliler } \\
\text { Arasında İhale Usulü }\end{array}$ & 37 & 0,21 & 541.622 & 4,07 & 14638,4 \\
\hline & Pazarlık Usulü & 949 & 5,48 & 1.086 .166 & 8,16 & 1144,5 \\
\hline & Toplam & 17.316 & 100,00 & 13.313.931 & 100,00 & - \\
\hline \multirow{4}{*}{2010} & Açık İhale Usulü & 16.268 & 94,90 & 9.632 .071 & 80,05 & 592,1 \\
\hline & $\begin{array}{l}\text { Belli İstekliler } \\
\text { Arasinda İhale Usulü }\end{array}$ & 92 & 0,54 & 1.251 .775 & 10,40 & 13606,3 \\
\hline & Pazarlık Usulü & 782 & 4,56 & 1.149 .335 & 9,55 & 1469,7 \\
\hline & Toplam & 17.142 & 100,00 & 12.033 .181 & 100,00 & - \\
\hline \multirow{4}{*}{2011} & Açık İhale Usulü & 20.826 & 95,35 & 14.103 .385 & 80,45 & 677,2 \\
\hline & $\begin{array}{l}\text { Belli İstekliler } \\
\text { Arasinda İhale Usulü }\end{array}$ & 111 & 0,51 & 2.831 .775 & 16,15 & 25511,5 \\
\hline & Pazarlık Usulü & 904 & 4,14 & 594.488 & 3,39 & 657,6 \\
\hline & Toplam & 21.841 & 100,00 & 17.529 .648 & 100,00 & - \\
\hline \multirow{4}{*}{2012} & Açık İhale Usulü & 19.387 & 93,81 & 18.602 .834 & 75,56 & 959,6 \\
\hline & $\begin{array}{l}\text { Belli İstekliler } \\
\text { Arasinda İhale Usulü }\end{array}$ & 144 & 0,70 & 4.007 .066 & 16,28 & 27826,8 \\
\hline & Pazarlık Usulü & 1.135 & 5,49 & 2.009 .057 & 8,16 & 1770,1 \\
\hline & Toplam & 20.666 & 100,00 & 24.618.957 & 100,00 & - \\
\hline \multirow{4}{*}{2013} & Açık İhale Usulü & 21.145 & 94,09 & 17.901 .419 & 73,37 & 846,6 \\
\hline & $\begin{array}{l}\text { Belli İstekliler } \\
\text { Arasında İhale Usulü }\end{array}$ & 127 & 0,57 & 3.882 .416 & 15,91 & 30570,2 \\
\hline & Pazarlık Usulü & 1.201 & 5,34 & 2.613 .996 & 10,71 & 2176,5 \\
\hline & Toplam & 22.473 & 100,00 & 24.397 .831 & 100,00 & - \\
\hline \multirow{4}{*}{2014} & Açık İhale Usulü & 15.587 & 94,14 & 14.230 .319 & 84,73 & 913,0 \\
\hline & $\begin{array}{l}\text { Belli İstekliler } \\
\text { Arasında İhale Usulü }\end{array}$ & 55 & 0,33 & 1.696 .982 & 10,10 & 30854,2 \\
\hline & Pazarlık Usulü & 916 & 5,53 & 867.905 & 5,17 & 947,5 \\
\hline & Toplam & 16.558 & 100,00 & 16.795 .206 & 100,00 & - \\
\hline
\end{tabular}




\begin{tabular}{|c|c|c|c|c|c|c|}
\hline Yillar & İhale Usulleri & Adet & $\begin{array}{c}\text { Adet } \\
\text { YıI İçi } \\
\%\end{array}$ & $\begin{array}{c}\text { Sözleşme } \\
\text { Bedeli } \\
\text { (USD) }\end{array}$ & $\begin{array}{c}\text { SB } \\
\text { YıI İçi } \\
\%\end{array}$ & $\begin{array}{l}\text { Birim } \\
\text { Sözleşme } \\
\text { Bedeli } \\
\text { (USD) }\end{array}$ \\
\hline \multirow{4}{*}{2015} & Açık İhale Usulü & 18.657 & 94,10 & 15.050 .876 & 82,45 & 806,7 \\
\hline & $\begin{array}{l}\text { Belli İstekliler } \\
\text { Arasında İhale Usulü }\end{array}$ & 68 & 0,34 & 1.675 .597 & 9,18 & 24641,1 \\
\hline & Pazarlık Usulü & 1.101 & 5,55 & 1.529 .001 & 8,38 & 1388,7 \\
\hline & Toplam & 19.826 & 100,00 & 18.255 .473 & 100,00 & - \\
\hline \multirow{4}{*}{2016} & Açık İhale Usulü & 18.347 & 93,26 & 16.406 .493 & 72,88 & 894,2 \\
\hline & $\begin{array}{l}\text { Belli İstekliler } \\
\text { Arasında İhale Usulü }\end{array}$ & 44 & 0,22 & 2.079 .299 & 9,24 & 47256,8 \\
\hline & Pazarlık Usulü & 1.283 & 6,52 & 4.025 .360 & 17,88 & 3137,5 \\
\hline & Toplam & 19.674 & 100,00 & 22.511 .152 & 100,00 & - \\
\hline \multirow{4}{*}{2017} & Açık İhale Usulü & 19.135 & 89,55 & 19.057 .959 & 54,85 & 996,0 \\
\hline & $\begin{array}{l}\text { Belli İstekliler } \\
\text { Arasında İhale Usulü }\end{array}$ & 71 & 0,33 & 5.908 .778 & 17,01 & 83222,2 \\
\hline & Pazarlık Usulü & 2.163 & 10,12 & 9.775 .963 & 28,14 & 4519,6 \\
\hline & Toplam & 21.369 & 100,00 & 34.742 .700 & 100,00 & - \\
\hline
\end{tabular}

2007-2017 yılları arasında gerçekleştirilen yapım işleri yıllara göre incelendiğinde, en fazla yapım işinin 22.473 adet ile 2013 yılında, en az yapım işinin ise 16.558 adet ile 2014 yılında gerçekleştirildiği görülmektedir. Ayrıca, en yüksek yapım işi sözleşme bedeli 34.742 .700 USD ile 2017 yılında gerçekleştirilmiş olup, en düşük yapım işi sözleşme bedeli 12.033.181 USD ile 2010 yılında gerçekleşmiştir. 2007-2017 yılları arasında gerçekleştirilen yapım işlerinin ihale usullerine göre dağılımı incelendiğinde, tüm yıllarda yapım işi ihalelerinin en fazla açık ihale usulü olarak gerçekleştirildiği görülmektedir. Pazarlık usulünün yapım işlerinde, açık ihale usulünden sonra en fazla tercih edilen ihale usulü olduğu, en az tercih edilen usulün ise belli istekliler arasında ihale usulü olduğu belirtilmelidir. Bunun yanında, tüm yıllarda en yüksek sözleşme bedeline sahip yapım işlerinin açık ihale usulü olarak gerçekleştirildiği dikkat çekmektedir. Buna karşın, tüm yıllarda en yüksek birim sözleşme bedeli belli istekliler arasında ihale usulü gerçekleştirilen yapım işlerinde görülmektedir.

2007-2017 yılları arasında gerçekleştirilen yapım işlerinin adet ve USD karşılığı sözleşme bedellerinin eşik değer durumuna göre dağılımı Çizelge 3'de verilmektedir. Çizelge'de adet ve sözleşme bedeli yıl içi yüzde oranları, sözleşme türlerinin o yıl içerisinde gerçekleşen toplam sözleşme adedi ve sözleşme bedeline oranını göstermekte olup ilgili yıla ait veriler dikkate alınarak hesaplanmaktadır. 
Çizelge 3 - 2007-2017 yılları arasında gerçekleştirilen yapım işlerinin eşik değer durumuna göre dă̆ılımı

\begin{tabular}{|c|c|c|c|c|c|c|}
\hline Yıllar & $\begin{array}{c}\text { Eşik Değer } \\
\text { Durumu }\end{array}$ & Adet & $\begin{array}{c}\text { Adet } \\
\text { Yıl İçi } \\
\%\end{array}$ & $\begin{array}{c}\text { Sözleşme } \\
\text { Bedeli } \\
\text { (USD) }\end{array}$ & $\begin{array}{c}\text { SB } \\
\text { Yıl İçi } \\
\%\end{array}$ & $\begin{array}{c}\text { Birim Sözleşme } \\
\text { Bedeli } \\
\text { (USD) }\end{array}$ \\
\hline \multirow{3}{*}{2007} & Altında & 20.514 & 99.09 & 8.707 .197 & 42.94 & 424.45 \\
\hline & Üstünde & 189 & 0.91 & 11.570 .839 & 57.06 & 61221.37 \\
\hline & Toplam & 20.703 & 100.00 & 20.278 .036 & 100.00 & - \\
\hline \multirow{3}{*}{2008} & Altında & 22.179 & 99.00 & 7.523 .222 & 43.08 & 339.20 \\
\hline & Üstünde & 223 & 1.00 & 9.938 .631 & 56.92 & 44567.85 \\
\hline & Toplam & 22.402 & 100.00 & 17.461 .853 & 100.00 & - \\
\hline \multirow{3}{*}{2009} & Altında & 17.309 & 98.78 & 6.497 .627 & 47.61 & 375.39 \\
\hline & Üstünde & 213 & 1.22 & 7.150 .525 & 52.39 & 33570.54 \\
\hline & Toplam & 17.522 & 100.00 & 13.648.151 & 100.00 & - \\
\hline \multirow{3}{*}{2010} & Altında & 16.983 & 99.07 & 7.764 .789 & 64.53 & 457.21 \\
\hline & Üstünde & 159 & 0.93 & 4.268 .392 & 35.47 & 26845.23 \\
\hline & Toplam & 17.142 & 100.00 & 12.033 .181 & 100.00 & - \\
\hline \multirow{3}{*}{2011} & Altında & 21.479 & 98.34 & 9.246 .143 & 52.75 & 430.47 \\
\hline & Üstünde & 362 & 1.66 & 8.283 .504 & 47.25 & 22882.61 \\
\hline & Toplam & 21.841 & 100.00 & 17.529 .648 & 100.00 & - \\
\hline \multirow{3}{*}{2012} & Altında & 20.250 & 97.99 & 11.511 .835 & 46.76 & 568.49 \\
\hline & Üstünde & 416 & 2.01 & 13.107.121 & 53.24 & 31507.50 \\
\hline & Toplam & 20.666 & 100.00 & 24.618 .956 & 100.00 & - \\
\hline \multirow{3}{*}{2013} & Altında & 22.067 & 98.19 & 11.632 .795 & 47.68 & 527.16 \\
\hline & Üstünde & 406 & 1.81 & 12.765 .036 & 52.32 & 31440.97 \\
\hline & Toplam & 22.473 & 100.00 & 24.397.831 & 100.00 & - \\
\hline \multirow{3}{*}{2014} & Altında & 16.290 & 98.38 & 8.612 .691 & 51.28 & 528.71 \\
\hline & Üstünde & 268 & 1.62 & 8.182 .514 & 48.72 & 30531.77 \\
\hline & Toplam & 16.558 & 100.00 & 16.795 .205 & 100.00 & - \\
\hline \multirow{3}{*}{2015} & Altında & 19.452 & 98.11 & 8.775 .262 & 48.07 & 451.12 \\
\hline & Üstünde & 374 & 1.89 & 9.480 .210 & 51.93 & 25348.16 \\
\hline & Toplam & 19.826 & 100.00 & 18.255 .472 & 100.00 & - \\
\hline
\end{tabular}




\begin{tabular}{|c|c|c|c|c|c|c|}
\hline Yıllar & $\begin{array}{c}\text { Eşik Değer } \\
\text { Durumu }\end{array}$ & Adet & $\begin{array}{c}\text { Adet } \\
\text { Yıl İçi } \\
\mathbf{\%}\end{array}$ & $\begin{array}{c}\text { Sözleşme } \\
\text { Bedeli } \\
\text { (USD) }\end{array}$ & $\begin{array}{c}\text { SB } \\
\text { Yıl İçi } \\
\mathbf{\%}\end{array}$ & $\begin{array}{c}\text { Birim Sözleşme } \\
\text { Bedeli } \\
\text { (USD) }\end{array}$ \\
\hline \multirow{4}{*}{$\mathbf{2 0 1 6}$} & Altında & 19.221 & 97.70 & 8.582 .485 & 38.13 & 446.52 \\
\cline { 2 - 7 } & Üstünde & 453 & 2.30 & 13.928 .666 & 61.87 & 30747.61 \\
\cline { 2 - 7 } & Toplam & $\mathbf{1 9 . 6 7 4}$ & $\mathbf{1 0 0 . 0 0}$ & $\mathbf{2 2 . 5 1 1 . 1 5 2}$ & $\mathbf{1 0 0 . 0 0}$ & - \\
\hline \multirow{3}{*}{$\mathbf{2 0 1 7}$} & Altında & 20.704 & 96.89 & 11.168 .058 & 32.15 & 539.42 \\
\cline { 2 - 7 } & Üstünde & 665 & 3.11 & 23.574 .642 & 67.85 & 35450.59 \\
\cline { 2 - 7 } & Toplam & $\mathbf{2 1 . 3 6 9}$ & $\mathbf{1 0 0 . 0 0}$ & $\mathbf{3 4 . 7 4 2 . 7 0 0}$ & $\mathbf{1 0 0 . 0 0}$ & - \\
\hline
\end{tabular}

2007-2017 yılları arasında gerçekleştirilen yapım işlerinin eşik değer durumuna göre dağılımı incelendiğinde, tüm yıllarda yapım işi ihalelerinin çoğunun eşik değerin altında olduğu görülmektedir. Buna karşın tüm yıllarda eşik değerin üstünde olan ihalelerin sözleşme bedelleri eşik değerin altında olan ihalelerin sözleşme bedellerinden daha yüksek olduğu dikkat çekmektedir.

2007-2017 yılları arasında gerçekleştirilen yapım işlerinin adet ve USD karşılığ 1 sözleşme bedellerinin sözleşme türlerine göre dağılımı Çizelge 4'de verilmektedir. Çizelge'de adet ve sözleşme bedeli yıl içi yüzde oranları, sözleşme türlerinin o yıl içerisinde gerçekleşen toplam sözleşme adedi ve sözleşme bedeline oranını göstermekte olup ilgili yıla ait veriler dikkate alınarak hesaplanmaktadır.

Çizelge 4 - 2007-2017 yılları arasında gerçekleştirilen yapım işlerinin sözleşme türlerine göre dă̆ılımı

\begin{tabular}{|c|l|c|c|c|c|c|}
\hline \multirow{2}{*}{ Yıllar } & \multicolumn{1}{|c|}{$\begin{array}{c}\text { Sözleşme } \\
\text { Türleri }\end{array}$} & Adet & $\begin{array}{c}\text { Adet } \\
\text { Yl İçi } \\
\mathbf{\%}\end{array}$ & $\begin{array}{c}\text { Sözleşme } \\
\text { Bedeli } \\
\text { (USD) }\end{array}$ & $\begin{array}{c}\text { SB Yıl } \\
\text { İçi } \\
\mathbf{\%}\end{array}$ & $\begin{array}{c}\text { Birim } \\
\text { Sözleşme } \\
\text { Bedeli } \\
\text { (USD) }\end{array}$ \\
\hline \multirow{2}{*}{$\mathbf{2 0 0 7}$} & Birim Fiyat & 7.482 & 36,15 & 10.494 .985 & 51,76 & 1402,7 \\
\cline { 2 - 8 } & $\begin{array}{l}\text { Anahtar Teslimi } \\
\text { Götürü Bedel }\end{array}$ & 13.216 & 63,85 & 9.783 .051 & 48,24 & 740,2 \\
\cline { 2 - 8 } & Karma & - & - & - & - & - \\
\cline { 2 - 8 } & Toplam & $\mathbf{2 0 . 6 9 8}$ & $\mathbf{1 0 0 , 0 0}$ & $\mathbf{2 0 . 2 7 8 . 0 3 6}$ & $\mathbf{1 0 0 , 0 0}$ & - \\
\hline \multirow{2}{*}{$\mathbf{2 0 0 8}$} & Birim Fiyat & 8.530 & 38,80 & 9.156 .471 & 54,03 & 1073,4 \\
\cline { 2 - 8 } & $\begin{array}{l}\text { Anahtar Teslimi } \\
\text { Götürü Bedel }\end{array}$ & 13.453 & 61,20 & 7.790 .855 & 45,97 & 579,1 \\
\cline { 2 - 8 } & Karma & - & - & - & - & - \\
\cline { 2 - 8 } & Toplam & $\mathbf{2 1 . 9 8 3}$ & $\mathbf{1 0 0 , 0 0}$ & $\mathbf{1 6 . 9 4 7 . 3 2 6}$ & $\mathbf{1 0 0 , 0 0}$ & - \\
\hline
\end{tabular}




\begin{tabular}{|c|c|c|c|c|c|c|}
\hline Yillar & $\begin{array}{l}\text { Sözleşme } \\
\text { Türleri }\end{array}$ & Adet & $\begin{array}{c}\text { Adet } \\
\text { Yıl İçi } \\
\text { \% }\end{array}$ & $\begin{array}{c}\text { Sözleşme } \\
\text { Bedeli } \\
\text { (USD) }\end{array}$ & $\begin{array}{c}\text { SB Yıl } \\
\text { İçi } \\
\%\end{array}$ & $\begin{array}{c}\text { Birim } \\
\text { Sözleşme } \\
\text { Bedeli } \\
\text { (USD) }\end{array}$ \\
\hline \multirow{4}{*}{2009} & Birim Fiyat & 5.827 & 33,65 & 6.127 .950 & 46,03 & 1051,6 \\
\hline & $\begin{array}{l}\text { Anahtar Teslimi } \\
\text { Götürü Bedel }\end{array}$ & 11.489 & 66,35 & 7.185 .981 & 53,97 & 625,5 \\
\hline & Karma & - & - & - & - & - \\
\hline & Toplam & 17.316 & 100,00 & 13.313.931 & 100,00 & - \\
\hline \multirow{4}{*}{2010} & Birim Fiyat & 6.815 & 39,76 & 6.658 .718 & 55,34 & 977,1 \\
\hline & $\begin{array}{l}\text { Anahtar Teslimi } \\
\text { Götürü Bedel }\end{array}$ & 10.327 & 60,24 & 5.374 .463 & 44,66 & 520,4 \\
\hline & Karma & - & - & - & - & - \\
\hline & Toplam & 17.142 & 100,00 & 12.033.181 & 100,00 & - \\
\hline \multirow{4}{*}{2011} & Birim Fiyat & 8.816 & 40,36 & 10.117 .931 & 57,72 & 1147,7 \\
\hline & $\begin{array}{l}\text { Anahtar Teslimi } \\
\text { Götürü Bedel }\end{array}$ & 12.924 & 59,17 & 7.055 .355 & 40,25 & 545,9 \\
\hline & Karma & 101 & 0,46 & 356.361 & 2,03 & 3528,3 \\
\hline & Toplam & 21.841 & 100,00 & 17.529 .648 & 100,00 & - \\
\hline \multirow{4}{*}{2012} & Birim Fiyat & 8.432 & 40,80 & 14.155 .558 & 57,50 & 1678,8 \\
\hline & $\begin{array}{l}\text { Anahtar Teslimi } \\
\text { Götürü Bedel }\end{array}$ & 12.131 & 58,70 & 9.976 .297 & 40,52 & 822,4 \\
\hline & Karma & 103 & 0,50 & 487.101 & 1,98 & 4729,1 \\
\hline & Toplam & 20.666 & 100,00 & 24.618 .956 & 100,00 & - \\
\hline \multirow{4}{*}{2013} & Birim Fiyat & 9.539 & 42,45 & 13.559 .535 & 55,58 & 1421,5 \\
\hline & $\begin{array}{l}\text { Anahtar Teslimi } \\
\text { Götürü Bedel }\end{array}$ & 12.819 & 57,04 & 9.896 .493 & 40,56 & 772,0 \\
\hline & Karma & 115 & 0,51 & 941.803 & 3,86 & 8189,6 \\
\hline & Toplam & 22.473 & 100,00 & 24.397.831 & 100,00 & - \\
\hline \multirow{4}{*}{2014} & Birim Fiyat & 6.681 & 40,35 & 8.791 .120 & 52,34 & 1315,8 \\
\hline & $\begin{array}{l}\text { Anahtar Teslimi } \\
\text { Götürü Bedel }\end{array}$ & 9.801 & 59,19 & 7.644 .414 & 45,52 & 780,0 \\
\hline & Karma & 76 & 0,46 & 359.672 & 2,14 & 4732,5 \\
\hline & Toplam & 16.558 & 100,00 & 16.795.206 & 100,00 & - \\
\hline
\end{tabular}




\begin{tabular}{|c|c|c|c|c|c|c|}
\hline Yillar & $\begin{array}{l}\text { Sözleşme } \\
\text { Türleri }\end{array}$ & Adet & $\begin{array}{c}\text { Adet } \\
\text { Yıl İçi } \\
\%\end{array}$ & $\begin{array}{c}\text { Sözleşme } \\
\text { Bedeli } \\
\text { (USD) }\end{array}$ & $\begin{array}{c}\text { SB Yıl } \\
\text { İçi } \\
\%\end{array}$ & $\begin{array}{l}\text { Birim } \\
\text { Sözleşme } \\
\text { Bedeli } \\
\text { (USD) }\end{array}$ \\
\hline \multirow{4}{*}{2015} & Birim Fiyat & 9.106 & 45,93 & 11.941 .431 & 65,41 & 1311,4 \\
\hline & $\begin{array}{l}\text { Anahtar Teslimi } \\
\text { Götürü Bedel }\end{array}$ & 10.607 & 53,50 & 5.734 .589 & 31,41 & 540,6 \\
\hline & Karma & 113 & 0,57 & 579.453 & 3,17 & 5127,9 \\
\hline & Toplam & 19.826 & 100,00 & 18.255.473 & 100,00 & - \\
\hline \multirow{4}{*}{2016} & Birim Fiyat & 9.338 & 47,46 & 14.756 .308 & 65,55 & 1580,2 \\
\hline & $\begin{array}{l}\text { Anahtar Teslimi } \\
\text { Götürü Bedel }\end{array}$ & 10.209 & 51,89 & 7.020 .255 & 31,19 & 687,7 \\
\hline & Karma & 127 & 0,65 & 734.589 & 3,26 & 5784,2 \\
\hline & Toplam & 19.674 & 100,00 & 22.511.152 & 100,00 & - \\
\hline \multirow{4}{*}{2017} & Birim Fiyat & 9.941 & 46,52 & 22.859 .659 & 65,80 & 2299,5 \\
\hline & $\begin{array}{l}\text { Anahtar Teslimi } \\
\text { Götürü Bedel }\end{array}$ & 11.290 & 52,83 & 10.049 .727 & 28,93 & 890,1 \\
\hline & Karma & 138 & 0,65 & 1.833 .314 & 5,28 & 13284,9 \\
\hline & Toplam & 21.369 & 100,00 & 34.742 .700 & 100,00 & - \\
\hline
\end{tabular}

2007-2017 yılları arasında gerçekleştirilen yapım işlerinin sözleşme türlerine göre dağılımı incelendiğinde, tüm yıllarda yapım işi sözleşmelerinin en fazla anahtar teslimi götürü bedel sözleşme ile gerçekleştirildiği görülmektedir. Birim fiyat sözleşmelerin yapım işlerinde, anahtar teslimi götürü bedel sözleşmelerden sonra en fazla tercih edilen sözleşme türü olduğu, en az tercih edilen sözleşme türünün ise karma sözleşmeler olduğu belirtilmelidir. Tüm yıllarda en yüksek sözleşme bedelinin ve 2007-2010 yılları arası en yüksek birim sözleşme bedelinin birim fiyat sözleşme ile gerçekleştirilen yapım işlerine ait olduğu görülmektedir. Buna karşın, 2011-2017 yılları arası en yüksek birim sözleşme bedelinin karma sözleşmelerde olduğu dikkat çekmektedir.

Çizelge 5'de 2007-2017 yılları arasında gerçekleştirilen yapım işlerinin sözleşme bedelinin yaklaşık maliyete oranı ile yaklaşık maliyet sözleşme bedeli farkı verilmektedir. Sözleşme bedeli ve yaklaşık maliyete ait veriler KİK raporlarından elde edilmiştir [11].

2007-2017 yılları arasında gerçekleştirilen yapım işlerinde sözleşme bedelinin yaklaşık maliyete oranı incelendiğinde en yüksek oran \% 80,79 ile 2008 yılında, en düşük oran \% 66,46 ile 2011 yılında görülmektedir. İdarelerin ihale öncesinde ihale konusu iş için hesapladıkları yaklaşık maliyetlerin doğru olduğu varsayımı altında, 4734 sayılı kanun kapsamında gerçekleştirilen yapım işinden elde edilen tasarruf, sözleşme bedeli ile yaklaşık maliyet arasındaki fark olup, en yüksek 11.014.952 USD 2011 yılında görülmektedir. 20072017 yılları arası gerçekleştirilen yapım işlerinden elde edilen toplam tasarruf tutarı 
Ihale Usulü ve Sözleşme Türünün Yapım İşi Sözleşme Bedeline Etkisinin Incelenmesi

78.849.487 USD ve sözleşme bedelinin yaklaşık maliyete oranın \% 73,74 olduğu görülmektedir.

Çizelge 5 - 2007-2017 yılları arasında gerçekleştirilen yapım işlerinin sözleşme bedelinin yaklaşık maliyete oranı

\begin{tabular}{|c|c|c|c|c|}
\hline Yıllar & $\begin{array}{c}\text { Sözleșme } \\
\text { Bedeli } \\
\text { (USD) }\end{array}$ & $\begin{array}{c}\text { Yaklaşık } \\
\text { Maliyet } \\
\text { (USD) }\end{array}$ & $\begin{array}{c}\text { YM - SB } \\
\text { (USD) }\end{array}$ & $\begin{array}{c}\text { SB/YM } \\
\text { (\%) }\end{array}$ \\
\hline $\mathbf{2 0 0 7}$ & 20.278 .035 & 25.100 .296 & 4.822 .261 & 80,79 \\
\hline $\mathbf{2 0 0 8}$ & 16.947 .326 & 21.846 .833 & 4.899 .507 & 77,57 \\
\hline $\mathbf{2 0 0 9}$ & 13.313 .931 & 18.529 .405 & 5.215 .473 & 71,85 \\
\hline $\mathbf{2 0 1 0}$ & 12.033 .181 & 16.514 .114 & 4.480 .933 & 72,87 \\
\hline $\mathbf{2 0 1 1}$ & 17.529 .649 & 26.377 .556 & 8.847 .907 & 66,46 \\
\hline $\mathbf{2 0 1 2}$ & 24.618 .957 & 35.633 .908 & 11.014 .952 & 69,09 \\
\hline $\mathbf{2 0 1 3}$ & 24.397 .831 & 33.961 .839 & 9.564 .008 & 71,84 \\
\hline $\mathbf{2 0 1 4}$ & 16.795 .206 & 23.042 .297 & 6.247 .091 & 72,89 \\
\hline $\mathbf{2 0 1 5}$ & 18.255 .473 & 25.395 .956 & 7.140 .483 & 71,88 \\
\hline $\mathbf{2 0 1 6}$ & 22.511 .152 & 29.753 .344 & 7.242 .193 & 75,66 \\
\hline $\mathbf{2 0 1 7}$ & 34.742 .700 & 44.117 .381 & 9.374 .680 & 78,75 \\
\hline Toplam & $\mathbf{2 2 1 . 4 2 3 . 4 4 1}$ & $\mathbf{3 0 0 . 2 7 2 . 9 2 8}$ & $\mathbf{7 8 . 8 4 9 . 4 8 7}$ & $\mathbf{7 3 , 7 4}$ \\
\hline Ortalama & $\mathbf{2 0 . 1 2 9 . 4 0 3 , 7 3}$ & $\mathbf{2 7 . 2 9 7 . 5 3 8 , 9 1}$ & $\mathbf{7 . 1 6 8 . 1 3 5 , 1 8}$ & $\mathbf{7 3 , 7 4}$ \\
\hline & & & & \\
\hline
\end{tabular}

Toplam sözleşme bedelinin toplam yaklaşık maliyete oranı 2007-2017 yılları arasında gerçekleştirilen yapım işlerinde idarece belirlenen 100 TL tutarındaki yaklaşık maliyetin 73,74 TL'sinin harcandığını veya işi yapan yükleniciye ödendiğini, kalan 26,26 TL'nin ise kullanılmadığını göstermektedir. Kullanılmayan 26,26 TL, ihalede istekliler tarafından en fazla \%26,26 oranında indirim yapıldığını göz önüne koymaktadır. SB/YM oranının \%73,74 olması isteklilerin idarelerce hesaplanan yaklaşık maliyetin altında teklif hazırladıklarını, dolayısıyla ihaleyi kazanmak için gerekli rekabet ortamının sağlandığını göstermektedir. Sonuç olarak 4734 sayılı kanun kapsamında gerçekleştirilen yapım işi ihalelerinde mevcut duruma göre idarelerce hesaplanan yaklaşık maliyetin sözleşme fiyatının üstünde olduğu görülmektedir.

Çizelge 6'da 2007-2017 yılları arasında gerçekleştirilen yapım işlerinin SB/YM oranının ihale usullerine göre verilmektedir. 
Çizelge 6 - 2007-2017 yılları arasında gerçekleştirilen yapım işlerinin SB/YM oranının ihale usullerine göre dă̆llımı

\begin{tabular}{|c|c|c|c|c|}
\hline Yillar & İhale Usulü & $\begin{array}{c}\text { Sözleşme } \\
\text { Bedeli (USD) }\end{array}$ & $\begin{array}{c}\text { Yaklaşık } \\
\text { Maliyet (USD) }\end{array}$ & $\begin{array}{c}\text { SB/YM } \\
\%\end{array}$ \\
\hline \multirow{4}{*}{2007} & Açık İhale Usulü & 17.928 .802 & 22.403 .064 & 80,03 \\
\hline & $\begin{array}{l}\text { Belli İstekliler } \\
\text { Arasında İhale Usulü }\end{array}$ & 1.258 .084 & 1.420 .493 & 88,57 \\
\hline & Pazarlık Usulü & 1.091 .150 & 1.276 .739 & 85,46 \\
\hline & Toplam & 20.278.035 & 25.100 .296 & 80,79 \\
\hline \multirow{4}{*}{2008} & Açık İhale Usulü & 15.338 .485 & 19.987 .279 & 76,74 \\
\hline & $\begin{array}{l}\text { Belli İstekliler } \\
\text { Arasında İhale Usulü }\end{array}$ & 749.893 & 930.161 & 80,62 \\
\hline & Pazarlık Usulü & 858.948 & 929.393 & 92,42 \\
\hline & Toplam & 16.947 .326 & 21.846.833 & $\mathbf{7 7 , 5 7}$ \\
\hline \multirow{4}{*}{2009} & Açık İhale Usulü & 11.686 .144 & 16.376 .249 & 71,36 \\
\hline & $\begin{array}{l}\text { Belli İstekliler } \\
\text { Arasında İhale Usulü }\end{array}$ & 541.622 & 941.929 & 57,50 \\
\hline & Pazarlık Usulü & 1.086 .166 & 1.211 .227 & 89,67 \\
\hline & Toplam & 13.313.931 & 18.529 .405 & 71,85 \\
\hline \multirow{4}{*}{2010} & Açık İhale Usulü & 9.632 .071 & 13.307 .588 & 72,38 \\
\hline & $\begin{array}{l}\text { Belli İstekliler } \\
\text { Arasında İhale Usulü }\end{array}$ & 1.251 .775 & 1.926 .910 & 64,96 \\
\hline & Pazarlık Usulü & 1.149 .335 & 1.279 .616 & 89,82 \\
\hline & Toplam & 12.033.181 & 16.514 .114 & 72,87 \\
\hline \multirow{4}{*}{2011} & Açık İhale Usulü & 14.103 .385 & 21.463 .020 & 65,71 \\
\hline & $\begin{array}{l}\text { Belli İstekliler } \\
\text { Arasında İhale Usulü }\end{array}$ & 2.831 .776 & 4.235 .933 & 66,85 \\
\hline & Pazarlık Usulü & 594.488 & 678.602 & 87,60 \\
\hline & Toplam & 17.529.649 & 26.377.556 & 66,46 \\
\hline \multirow{4}{*}{2012} & Açık İhale Usulü & 18.602 .833 & 27.591 .756 & 67,42 \\
\hline & $\begin{array}{l}\text { Belli İstekliler } \\
\text { Arasında İhale Usulü }\end{array}$ & 4.007 .066 & 5.752 .910 & 69,65 \\
\hline & Pazarlık Usulü & 2.009 .057 & 2.289 .242 & 87,76 \\
\hline & Toplam & 24.618.957 & 35.633 .908 & 69,09 \\
\hline
\end{tabular}




\begin{tabular}{|c|c|c|c|c|}
\hline Yillar & İhale Usulü & $\begin{array}{c}\text { Sözleşme } \\
\text { Bedeli (USD) }\end{array}$ & $\begin{array}{c}\text { Yaklaşık } \\
\text { Maliyet (USD) }\end{array}$ & $\begin{array}{c}\text { SB/YM } \\
\%\end{array}$ \\
\hline \multirow{4}{*}{2013} & Açık İhale Usulü & 17.901 .419 & 25.654 .046 & 69,78 \\
\hline & $\begin{array}{l}\text { Belli İstekliler } \\
\text { Arasinda İhale Usulü }\end{array}$ & 3.882 .416 & 5.284 .235 & 73,47 \\
\hline & Pazarlık Usulü & 2.613 .996 & 3.023 .558 & 86,45 \\
\hline & Toplam & 24.397 .831 & 33.961.839 & 71,84 \\
\hline \multirow{4}{*}{2014} & Açık İhale Usulü & 14.230 .319 & 19.800 .361 & 71,87 \\
\hline & $\begin{array}{l}\text { Belli İstekliler } \\
\text { Arasında İhale Usulü }\end{array}$ & 1.696 .982 & 2.221 .136 & 76,40 \\
\hline & Pazarlık Usulü & 867.905 & 1.020 .799 & 85,02 \\
\hline & Toplam & 16.795 .206 & 23.042.297 & 72,89 \\
\hline \multirow{4}{*}{2015} & Açık İhale Usulü & 15.050 .876 & 21.461 .883 & 70,13 \\
\hline & $\begin{array}{l}\text { Belli İstekliler } \\
\text { Arasında İhale Usulü }\end{array}$ & 1.675 .597 & 2.236 .865 & 74,91 \\
\hline & Pazarlık Usulü & 1.529 .001 & 1.697 .208 & 90,09 \\
\hline & Toplam & 18.255 .473 & 25.395 .956 & 71,88 \\
\hline \multirow{4}{*}{2016} & Aç1k İhale Usulü & 16.406 .493 & 22.552 .871 & 72,75 \\
\hline & \begin{tabular}{|l|} 
Belli İstekliler \\
Arasinda İhale Usulü \\
\end{tabular} & 2.079.299 & 2.550 .297 & 81,53 \\
\hline & Pazarlık Usulü & 4.025 .360 & 4.650 .176 & 86,56 \\
\hline & Toplam & 22.511 .152 & 29.753 .344 & 75,66 \\
\hline \multirow{4}{*}{2017} & Açık İhale Usulü & 19.057 .959 & 25.908 .081 & 73,56 \\
\hline & $\begin{array}{l}\text { Belli İstekliler } \\
\text { Arasında İhale Usulü }\end{array}$ & 5.908 .778 & 6.675 .867 & 88,51 \\
\hline & Pazarlık Usulü & 9.775 .963 & 11.533 .433 & 84,76 \\
\hline & Toplam & 34.742 .700 & 44.117.381 & 78,75 \\
\hline
\end{tabular}

2007-2017 yılları arasında gerçekleştirilen yapım işlerinin SB/YM oranının ihale usullerine göre dağılımı incelendiğinde, yıllara göre değişmekle beraber genellikle en yüksek oranın pazarlık usulü gerçekleştirilen yapım işi ihalelerinde, en düşük oranın ise açık ihale usulü gerçekleştirilen yapım işi ihalelerinde olduğu görülmektedir. Buna göre, genellikle en fazla indirimin açık ihale usulü gerçekleştirilen yapım işi ihalelerinde, en az indirimin ise pazarlık usulü gerçekleştirilen yapım işi ihalelerinde olduğu yorumu yapılabilmektedir. 


\section{YÖNTEM}

Çalışma kapsamında,

- ihale usulünün yapım işlerine ait birim sözleşme bedellerine etkisi,

- ihale eşik değer durumunun yapım işlerine ait birim sözleşme bedellerine etkisi

- sözleşme türünün yapım işlerine ait birim sözleşme bedellerine etkisi,

- ihale usulünün yapım işlerine ait SB/YM oranlarına etkisi

istatistiksel analizler aracılığıyla incelenmiştir.

İstatistiksel testlerden bazılarının teorisi, veri gruplarının normal dağılıma uygun olması ve homojen olması varsayımı üzerine kurulmuştur [12]. Bu nedenle, doğru testin belirlenmesi için öncelikle veri gruplarının normal dağılıma uyup uymadığının ve varyanslarının homojen olup olmadığının araştırılması gerekmektedir. Bu çalışmada gerçekleştirilecek analizler için ilk olarak, her yıla ait birim sözleşme bedelleri hesaplanmıştır. Daha sonra, birim sözleşme bedellerinin (1) ihale usullerine, (2) sözleşme türlerine ve (3) SB/YM oranlarının ihale usullerine göre normal dağılıp dağılmadığı normallik testleri ile belirlenmiştir. Normallik testleri arasında Wilk tarafindan geliştirilen Shapiro-Wilk testi en güçlü testlerden biri olarak gösterilmektedir [13]. Shapiro-Wilk testinin kullanılabilmesi için örnek hacminin 7'den büyük veya 2000'den küçük veya 2000'e eşit olması gerekmektedir. Bu çalışmada kullanılan veri sayısı (N=11) Shapiro-Wilk testinin kullanılabilmesi için uygun olduğundan normallik bu yöntem ile test edilmiştir. Normallik testlerinin sonuçlarına bağlı olarak SB/YM oranının ihale usullerine göre varyanslarının homojenliğinin araştırması gerekmekte olup bunun için Levene testi gerçekleştirilmiştir. Bu test, $\mathrm{N}$ adet örneklemin, alındığ eşit olup olmadığını test eden parametrik olmayan bir testtir [12] ve istatistiksel paket programları (örn. SPPS, minitab) homojenlik testi için bu testi kullanmaktadır. Bu testlerin sonuçlarına göre, analizler için uygun istatistiksel testler belirlenmiştir.

Gerçekleştirilen normallik testlerinin sonuçlarına göre, birim sözleşme bedellerinin ihale usullerine ve sözleşme türlerine göre normal dağılmadığı tespit edilmiştir. Bu nedenle, birim sözleşme bedellerinin ihale usullerine ve sözleşme türlerine göre anlamlı bir şekilde farklılaşıp farklılaşmadığını test etmek amacıyla oldukça güçlü olan ve sıklıkla kullanılan parametrik olmayan Kruskal-Wallis testi gerçekleştirilmiştir [14-20]. Bu test tek yönlü varyans analizi yöntemi olup $\mathrm{n}$ bağımsız örneklemin x puanlarının dağılımının benzer ortanca değerli toplumların rasgele örnekleri olup olmadığını test etmek için kullanılır [13]. Bu testte veri değerleri sıralı hale getirilir, sıra toplamları grup büyüklügüne bölünerek sıra ortalamaları hesaplanır ve bu ortalamalar karşılaştırılır [21]. Ortalamalar arasında istatistiksel olarak anlamlı bir fark tespit edildiğinde bu farklılığın kaynağını bulmak için parametrik olmayan testlerde yaygın kullanılan çoklu karşılaştırma testi olmaması nedeniyle, başka çalışmalarda olduğu gibi ihale usulleri ve sözleşme türlerinin ikili grupları için MannWhitney U testleri gerçekleştirilmiştir [16-18, 22, 23]. Mann-Whitney U test sadece iki grup arasında yapılabilen ve grupların medyanlarını karşılaştıran bir testtir. Böylece, iki grup arasındaki sıralamanın farklı olup olmadığını değerlendirir [15].

İhale usullerinin SB/YM oranlarına etkisinin analizinde ise normallik dağılımı koşulu sağlanması ancak varyansların homojenliği şartının sağlanmaması nedeniyle heterojen varyanslılığa karşı dayanaklı parametre dışı olan ve uygulamalarda sıklıkla kullanılan Welch 
testi gerçekleştirilmiştir [24-26]. Bu test sayesinde SB/YM oranlarının ihale usullerine göre ortalamaları arasındaki farkın istatistiksel olarak anlamlı olup olmadığ belirlenmiştir. Daha sonra bu farkın hangi ihale usulleri arasındaki farklardan kaynaklandığının tespiti için, varyansların homojenliği varsayımının sağlanmadığı durumlarda kullanılan çoklu karşılaştırma testlerinden biri olan Games-Howell testi gerçekleştirilmiştir [23, 25-27].

\section{ANALIZLER}

\subsection{Sözleşme Bedelinin İhale Usullerine Göre Analizi}

Birim sözleşme bedellerinin ihale usullerine göre dağılımları için Shapiro-Wilk normallik testi gerçekleştirilmiş olup sonuçlar Çizelge 7'de sunulmaktadır. Sonuçlar incelendiğinde, belli istekliler arasında ihale ve pazarlık usullerine göre birim sözleşme bedellerinin $p$ değerlerinin sirasıyla, 0,003 ve 0,0019 olduğu görülmektedir. Bu değerler, 0,05 anlamlılık düzeyinden küçük olduğu için bu usullere ait birim sözleşme bedellerinin normal dağılmadıkları tespit edilmiştir.

Çizelge 7 - Birim sözleşme bedellerinin ihale usullerine göre Shapiro-Wilk test sonuçları

\begin{tabular}{|c|c|c|c|}
\hline İhale usulü & İstatistik & $\begin{array}{c}\text { Serbestlik } \\
\text { derecesi (sd) }\end{array}$ & $\boldsymbol{p}$ \\
\hline Açık ihale usulü & 0,954 & 11 & 0,700 \\
\hline $\begin{array}{c}\text { Belli istekliler } \\
\text { arasında ihale } \\
\text { usulü }\end{array}$ & 0,760 & 11 & 0,003 \\
\hline Pazarlık usulü & 0,823 & 11 & 0,019 \\
\hline
\end{tabular}

Birim sözleşme bedelleri tüm ihale usullerine göre normallik şartını sağlamadığı için birim sözleşme bedellerinin ihale usullerine göre anlamlı bir şekilde farklılaşıp farklılaşmadığını test etmek amacıyla parametrik olmayan Kruskal-Wallis testi seçilmiş ve sonuçları Çizelge 8 'de verilmektedir.

Çizelge 8 - Birim sözleşme bedellerinin ihale usullerine göre Kruskal-Wallis test sonuçları

\begin{tabular}{|c|c|c|c|c|c|c|}
\hline Boyut & İhale Usulü & $\mathbf{N}$ & $\begin{array}{c}\text { Sira } \\
\text { ortalama }\end{array}$ & Sd & Ki-kare & $p$ \\
\hline \multirow{3}{*}{$\begin{array}{l}\text { Birim } \\
\text { Sözleşme } \\
\text { Bedeli }\end{array}$} & Açık ihale usulü & 11 & 7,55 & \multirow{3}{*}{2} & \multirow{3}{*}{25,033} & \multirow{3}{*}{0,000} \\
\hline & $\begin{array}{l}\text { Belli istekliler arasinda } \\
\text { ihale usulü }\end{array}$ & 11 & 28,00 & & & \\
\hline & Pazarlık usulü & 11 & 15,45 & & & \\
\hline
\end{tabular}


Grupların Çizelge 8'deki sıra ortalamaları incelendiğinde, belli istekliler arasında ihale usulü gerçekleştirilen yapım işlerinde birim sözleşme bedelinin, açık ihale ve pazarlık usulü gerçekleştirilen yapım işlerindekilere göre daha yüksek olduğu görülmektedir. Ayrıca pazarlık usulü gerçekleştirilen yapım işlerinde birim sözleşme bedelinin açık ihale usulü gerçekleştirilen yapım işlerindekinden daha yüksek olduğu ifade edilebilir. Kruskal-Wallis test sonuçları incelendiğinde, açık ihale, belli istekliler arasında ihale ve pazarlık usulü gerçekleştirilen yapım işlerinin birim sözleşme bedelleri arasında istatistiksel olarak anlamlı bir fark olduğu görülmektedir $(p=0,000 ; p<0,05)$.

Farklılığın kaynağını anlayabilmek için Mann-Whitney U testleri gerçekleştirilmiştir. Bu testlerin sonuçları Çizelge 9'da sunulmaktadır. Elde edilen $p$ değerlerinin hepsi 0,05'den küçük olduğu için istatistiksel olarak anlamlı farklılık tüm ihale usulleri arasında tespit edilmiştir. $\mathrm{Bu}$ durumda, ihale usulünün yapım işleri birim sözleşme bedelleri üzerine istatistiksel olarak anlamlı bir etkisi olduğu yorumu yapılabilmektedir.

\section{Çizelge 9 - Birim sözleşme bedellerinin ihale usullerine göre Mann-Whitney U test} sonuçları

\begin{tabular}{|c|c|c|c|c|}
\hline & \multicolumn{3}{|c|}{ İhale Usulü } \\
\hline & & $\begin{array}{l}\text { Açık ihale } \\
\text { usulü }\end{array}$ & $\begin{array}{c}\text { Belli istekliler } \\
\text { arasında ihale usulü }\end{array}$ & $\begin{array}{c}\text { Pazarlık } \\
\text { usulü }\end{array}$ \\
\hline \multirow{3}{*}{ 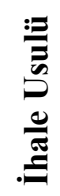 } & Açık ihale usulü & - & 0,000 & 0,004 \\
\hline & $\begin{array}{c}\text { Belli istekliler } \\
\text { arasında ihale usulü }\end{array}$ & 0,000 & - & 0,000 \\
\hline & Pazarlık usulü & 0,004 & 0,000 & - \\
\hline
\end{tabular}

\subsection{Sözleşme Bedelinin Eşik Değer Durumuna Göre Analizi}

Birim sözleşme bedellerinin eşik değere göre dağılımları için Shapiro-Wilk normallik testi gerçekleştirilmiş olup sonuçlar Çizelge 10'da sunulmaktadır. Sonuçlar incelendiğinde, ihale bedelinin eşik değerinin altında ve üstünde olması durumuna göre birim sözleşme bedellerinin $p$ değerlerinin sırasıyla, 0,643 ve 0,11 olduğu görülmektedir. Bu durumda ihale bedelleri eşik değerinin altında olan ihalelerin birim sözleşme bedelleri normal dağılırken $(p=0,643>0,05)$ ihale bedelleri eşik değerinin üstünde olan birim sözleşme bedellerinin normal dağılmadıkları $(p=0,11<0,05)$ tespit edilmiştir.

Çizelge 10 - Birim sözleşme bedellerinin eşik değerine göre Shapiro-Wilk test sonuçları

\begin{tabular}{|c|c|c|c|}
\hline İhale Bedeli & İstatistik & $\begin{array}{c}\text { Serbestlik } \\
\text { derecesi (sd) }\end{array}$ & $\boldsymbol{p}$ \\
\hline Eşik değeri altında & 0,950 & 11 & 0,643 \\
\hline Eşik değeri üstünde & 0,804 & 11 & 0,11 \\
\hline
\end{tabular}


Birim sözleşme bedelleri tüm ihale bedellerine göre normallik şartını sağlamadığ için birim sözleşme bedellerinin ihale bedelinin eşik değerinin altında veya üstünde olmasına göre anlamlı bir şekilde farklılaşıp farklılaşmadığını test etmek amacıyla parametrik olmayan Mann-Whitney U testi seçilmiş olup sonuçları Çizelge 11'de verilmektedir.

Çizelge 11 - Birim sözleşme bedellerinin ihale bedeline göre Mann-Whitney U test sonuçları

\begin{tabular}{|c|c|c|c|c|c|}
\hline Boyut & İhale Bedeli & $\mathbf{N}$ & $\begin{array}{c}\text { Sıra } \\
\text { ortalama }\end{array}$ & $\begin{array}{c}\text { Mann- } \\
\text { Whitney U }\end{array}$ & $\boldsymbol{p}$ \\
\hline $\begin{array}{c}\text { Birim } \\
\text { Sözleşme } \\
\text { Bedeli }\end{array}$ & Eşik değeri altında & 11 & 6,00 & \multirow{2}{*}{0,000} & 0,000 \\
\cline { 2 - 4 } & Eşik değeri üstünde & 11 & 17,00 & 0,000 \\
\hline
\end{tabular}

Grupların Çizelge 11 'deki sıra ortalamaları incelendiğinde, ihale bedelinin eşik değerinin üstünde olduğu birim sözleşme bedelinin, ihale bedelinin eşik değerinin altında olduğu duruma göre daha yüksek olduğu görülmektedir. Mann-Whitney U test sonuçları incelendiğinde, ihale bedelinin eşik değeri altında veya üstünde olmasının birim sözleşme bedelleri üzerinde istatistiksel olarak anlamlı bir fark yarattığı görülmektedir $(p=0,000$; $p<0,05)$.

\subsection{Sözleşme Bedelinin Sözleşme Türlerine Göre Analizi}

Birim sözleşme bedellerinin ihale usullerine göre dağılımları için Shapiro-Wilk normallik testi gerçekleştirilmiş olup sonuçları Çizelge 12'de sunulmaktadır. Sonuçlar incelendiğinde, karma sözleşme türüne ait $p$ değerinin $(0,039) 0,05$ anlamlılık değerinden küçük olduğu ve bu nedenle normal dağılmadığı görülmektedir.

Çizelge 12 - Birim sözleşme bedellerinin sözleşme türlerine göre Shapiro-Wilk test sonuçları

\begin{tabular}{|c|c|c|c|}
\hline Sözleşme türü & İstatistik & Sd & $\boldsymbol{p}$ \\
\hline Birim fiyat & 0,876 & 11 & 0,092 \\
\hline $\begin{array}{c}\text { Anahtar teslimi götürü } \\
\text { bedel }\end{array}$ & 0,931 & 11 & 0,420 \\
\hline Karma & 0,798 & 7 & 0,039 \\
\hline
\end{tabular}

Birim sözleşme bedelleri tüm sözleşme türlerine göre normallik şartını sağlamadığı için birim sözleşme bedellerinin sözleşme türlerine göre anlamlı bir şekilde farklılaşıp farklılaşmadığını test etmek amacıyla parametrik olmayan Kruskal-Wallis testi seçilmiş olup sonuçlar Çizelge $13^{\prime}$ 'de verilmektedir. 
Çizelge 13 - Birim sözleşme bedellerinin sözleşme türlerine göre Kruskal-Wallis test sonuçları

\begin{tabular}{|c|c|c|c|c|c|c|}
\hline Boyut & Sözleşme türü & $\mathbf{N}$ & $\begin{array}{c}\text { Sira } \\
\text { ortalama }\end{array}$ & Sd & Ki-kare & $\boldsymbol{p}$ \\
\hline \multirow{2}{*}{$\begin{array}{c}\text { Birim } \\
\text { Sözleşme } \\
\text { Bedeli }\end{array}$} & Birim fiyat & 11 & 17 & & & \\
\cline { 2 - 4 } & $\begin{array}{c}\text { Anahtar teslimi } \\
\text { götürü bedel }\end{array}$ & 11 & 6 & 2 & 24,579 & 0,000 \\
\cline { 2 - 4 } & Karma & 7 & 26 & & \\
\hline
\end{tabular}

Grupların Çizelge 13'deki sıra ortalamaları dikkate alındığında karma sözleşme ile gerçekleştirilen yapım işlerinin birim sözleşme bedellerinin birim fiyat ve anahtar teslimi götürü bedel ile gerçekleştirilen yapım işlerindekilere göre daha yüksek olduğu görülmektedir. Bunun yanında, birim fiyat sözleşme ile gerçekleştirilen yapım işlerinin birim sözleşme bedellerinin anahtar teslim götürü bedel ile gerçekleştirilen yapım işlerininkinden daha yüksek olduğu belirtilmelidir. Kruskal Wallis testinin sonucu incelendiğinde birim fiyat, anahtar teslim götürü bedel ve karma sözleşme ile gerçekleştirilen yapım işlerinin birim sözleşme bedelleri arasında istatistiksel olarak anlamlı bir fark olduğu görülmektedir $(p=0,000 ; \mathrm{p}<0,05)$.

Farklılığın kaynağını anlayabilmek Mann-Whitney U testleri gerçekleştirilmiştir. Bu testlerin sonuçları Çizelge 14'de sunulmaktadır. Elde edilen $p$ değerlerinin hepsi 0,05'den küçük olduğu için istatistiksel olarak anlamlı farklılığın tüm sözleşme türleri arasında olduğu tespit edilmiştir. Bu durumda, sözleşme türünün yapım işleri birim sözleşme bedelleri üzerine istatistiksel olarak anlamlı bir etkisi olduğu yorumu yapılabilmektedir.

Çizelge 14 - Birim sözleşme bedellerinin sözleşme türlerine göre Mann-Whitney U test sonuçları

\begin{tabular}{|c|c|c|c|c|}
\hline & \multicolumn{3}{|c|}{ Sözleşme Türü } \\
\hline & & Birim fiyat & $\begin{array}{c}\text { Anahtar teslimi } \\
\text { götürü bedel }\end{array}$ & Karma \\
\hline \multirow{3}{*}{ 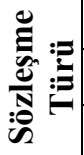 } & Birim fiyat & - & 0,000 & 0,000 \\
\hline & Anahtar teslimi götürü bedel & 0,000 & - & 0,000 \\
\hline & Karma & 0,000 & 0,000 & - \\
\hline
\end{tabular}

\subsection{Sözleşme Bedeli Yaklaşık Maliyet Oranının İhale Usullerine Göre Analizi}

SB/YM oranlarının ihale usullerine göre dağılımları için Shapiro-Wilk normallik testi gerçekleştirilmiş olup sonuçlar Çizelge $15^{\prime}$ 'de sunulmaktadır. Sonuçlar incelendiğinde, ihale usullerine göre SB/YM oranlarının $p$ değerlerinin 0,05 anlamlılık düzeyinden büyük olduğu görülmektedir. $\mathrm{Bu}$ nedenle, SB/YM oranlarının ihale usullerine göre normal dağıldığ1 varsayımı kabul edilebilmektedir. Normallik şartının sağlanması nedeniyle, verilerin 
varyanslarının homojenliği, Levene'nin testi ile kontrol edilmiştir. Test sonucundaki $p$ değeri 0,002 olarak elde edilmiştir. Bu değer, 0,05 anlamlılık düzeyinden küçük olduğu için ihale usullerine göre SB/YM oranlarının varyanslarının homojen olduğu varsayımı reddedilmiştir.

Çizelge 15 - SM/YM oranlarının sözleşme türlerine göre Shapiro-Wilk ve Levene'nin test sonuçları

\begin{tabular}{|c|c|c|c|c|c|c|c|}
\hline & \multicolumn{3}{|c|}{ Shapiro-Wilk Test } & \multicolumn{4}{|c|}{ Levene'nin Testi } \\
\hline İhale usulü & İstatistik & Sd & $\boldsymbol{p}$ & İstatistik & Sd1 & Sd2 & $\boldsymbol{p}$ \\
\hline Açık ihale usulü & 0,954 & 11 & 0,700 & & & & \\
\cline { 1 - 5 } $\begin{array}{c}\text { Belli istekliler arasında ihale } \\
\text { usulü }\end{array}$ & 0,760 & 11 & 0,003 & 7,413 & 2 & 30 & 0,002 \\
\cline { 1 - 5 } Pazarlık usulü & 0,823 & 11 & 0,019 & & & & \\
\hline
\end{tabular}

Normallik şartı sağlandığı ancak homojenlik şartı sağlanmadığı için SB/YM oranlarının ihale usullerine göre anlamlı bir şekilde farklılaşıp farklılaşmadığını test etmek amacıyla Welch testi seçilmiş olup sonuçları Çizelge 16'da sunulmaktadır.

Çizelge 16 - SM/YM oranlarının sözleşme türlerine göre Welch test sonuçları

\begin{tabular}{|c|c|c|c|c|c|c|c|}
\hline Boyut & İhale Usulü & $\mathbf{N}$ & Ortalama & Sd1 & Sd2 & $\begin{array}{c}\text { Asimptotik } \\
\text { F }\end{array}$ & $p$ \\
\hline \multirow{3}{*}{$\mathrm{SB} / \mathrm{YM}$} & Açık ihale usulü & 11 & 0,72 & \multirow{3}{*}{2} & \multirow{3}{*}{17,17} & \multirow{3}{*}{64,32} & \multirow{3}{*}{0,0} \\
\hline & $\begin{array}{l}\text { Belli istekliler } \\
\text { arasında ihale } \\
\text { usulü }\end{array}$ & 11 & 0,75 & & & & \\
\hline & Pazarlık usulü & 11 & 0,88 & & & & \\
\hline
\end{tabular}

Çizelge 16'da ihale usullerine göre SB/YM oranları karşılaştırıldığında en yüksek ortalamanın $(0,88)$ pazarlık usulü gerçekleştirilen yapım işlerine ait olduğu görülmektedir. Bununla birlikte, belli istekliler arasında ihale usulü gerçekleştirilen yapım işlerinin SB/YM oranlarının ortalamasının $(0,75)$ açık ihale usulü gerçekleştirilen yapım işlerinin ortalasına $(0,72)$ göre yüksek olduğu ancak aradaki farkın çok fazla olmadığı görülmektedir. Welch testinin sonuçları incelendiğinde, asimptotik $\mathrm{F}$ istatistiği için $p$ değeri 0,000 olarak elde edilmiştir. Bu değer, 0,05 anlamlılık düzeyinden küçük olduğu için ihale usullerine göre $\mathrm{SB} / \mathrm{YM}$ oranlarının ortalaması arasında istatistiksel olarak anlamlı bir fark olduğu belirlenmiştir.

Farklılığın kaynağını anlayabilmek için çoklu karşılaştırma testlerinden Games-Howell testi kullanılmıştır. Bu teste ait sonuçlar Çizelge 17'de görülmektedir. Açık ihale usulü ile pazarlık usulü ve belli istekliler arasında ihale usulü ile pazarlık usulü arasındaki $p$ değerleri sırasıyla 0,000 ve 0,003 olarak elde edilmiştir. Bu iki değer 0,05 anlamlılık düzeyinden küçük olduğu 
için farklılığın yönü açık ihale usulü-pazarlık usulü ve belli istekliler arasında ihale usulüpazarlık usulü olarak bulunmuştur. $\mathrm{Bu}$ durumda, pazarlık usulünün SB/YM oranının farklılaşmasına neden olduğu yorumu yapılabilmektedir.

Çizelge 17 - SB/YM oranlarının ihale usullerine göre Games-Howell test sonuçları

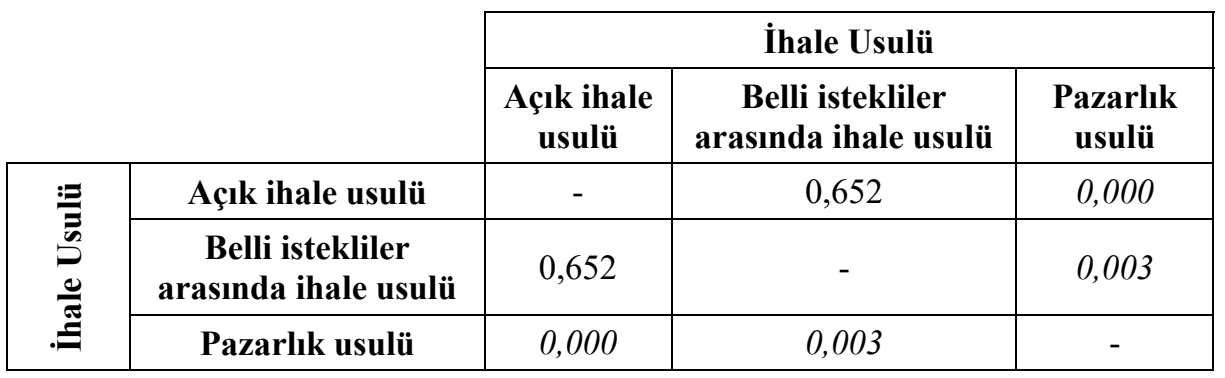

\section{TARTIŞMA}

Bu çalışmada, 2007-2017 yılları arasında 4734 sayılı kanun kapsamında gerçekleştirilen yapım işi kamu alım istatistikleri incelenmiştir. Yapılan değerlendirmelerden elde edilen başlıca sonuçlar aşağıda sunulmaktadır;

- 2007-2017 yılları arasında yapım işlerinde en yüksek toplam sözleşme bedeli (34.742.700 USD) 2017 yılında, en düşük sözleşme bedeli (12.033.181 USD) ise 2010 yılında görülmektedir.

- 2007-2017 yılları arasında en yüksek sözleşme bedeli açık ihale usulü olarak gerçekleştirilen yapım işlerinde görülmekte iken en yüksek birim sözleşme bedeli belli istekliler arasında ihale usulü olarak gerçekleştirilen yapım işlerinde görülmektedir.

- 2007-2017 yılları arasında gerçekleştirilen yapım işi ihalelerinin çoğunun eşik değerin altında olduğu görülmektedir.

- 2007-2017 yılları arasında eşik değerin üstünde olan yapım işi ihalelerinin sözleşme bedellerinin eşik değerin altında olan yapım işi ihalelerinin sözleşme bedellerinden daha yüksek olduğu görülmektedir.

- 2007-2017 yılları arasında en yüksek sözleşme bedelinin ve 2007-2010 yılları arası en yüksek birim sözleşme bedelinin birim fiyat sözleşme ile gerçekleştirilen yapım işlerine ait olduğu görülmektedir. Buna karşın, 2011-2017 yılları arası en yüksek birim sözleşme bedelinin karma sözleşmelerde olduğu dikkat çekmektedir.

- 2007-2017 yılları arasında yapım işlerinde SB/YM oranı en fazla $(\%$ 80,79) 2008 yılında, en az ise $(\% 66,46) 2011$ yılında görülmektedir.

- 2007-2017 yılları arasında yapım işlerinde en yüksek tasarruf (11.014.952 USD) 2011 yılında görülmektedir. 
- 2007-2017 yılları arasında SB/YM oranı yıllara göre değişmekle beraber en yüksek pazarlık usulü olarak gerçekleştirilen, en düşük açık ihale usulü olarak gerçekleştirilen yapım işlerinde görülmektedir.

- Genellikle en fazla indirimin açık ihale usulü gerçekleştirilen yapım işi ihalelerinde, en az indirimin ise pazarlık usulü gerçekleştirilen yapım işi ihalelerinde olduğu sonucu ortaya çıkmaktadır.

Bunun yanında, (1) sözleşme bedeline ihale usulünün, (2) sözleşme bedeli ve ihale eşik değer durumu (3) sözleşme bedeline sözleşme türünün ve (4) SB/YM oranına ihale usulünün etkisinin olup olmadığı istatistiksel analizler yardımıyla incelenmiştir. Çalışmanın sonuçları, sözleşme türünün yapım işleri sözleşme bedelleri üzerinde istatistiksel olarak anlamlı bir etkisi olduğunu göstermektedir. Benzer şekilde, Elhag vd. [7], Skitmore ve Ng [8], Drew vd. [9] sözleşme türünün, sözleşme bedeli üzerinde etkisi olduğunu ortaya koymuşlardır. Literatürde yer alan çalışmalar, sözleşme bedeli üzerinde etkisi olan bir diğer faktörün sözleşme büyüklüğü olduğunu göstermektedir [7-9]. Özellikle, proje büyüklüğünün ihale sonucunda ortaya çıkacak sözleşme bedelini en çok etkileyen faktör olduğu ortaya konulmuştur [9]. Bu çalışmanın sonuçları da literatürdeki sonuçlar ile paralellik göstermiş ve ihale bedelinin eşik değeri altında veya üstünde olmasının, bir başka deyişle proje büyüklüğünün, sözleşme bedelleri üzerinde istatistiksel olarak anlamlı bir fark yarattığı tespit edilmiştir.

Bu çalışmadan elde edilen bir başka sonuç, ihale usulünün yapım işleri sözleşme bedelleri üzerinde istatistiksel olarak anlamlı bir etki yarattı̆̆ıdır. Bunun yanında ihale usulünün SB/YM oranına etkisi olduğu da görülmektedir. Analiz sonuçlarına göre, pazarlık usulü ile yapılan ihaleler diğer usullere göre SB/YM oranında istatistiksel olarak anlamlı bir fark yaratırken, açık ihale usulu veya belli istekliler arasında ihale usulü tercih edilerek yapılan ihalelerin sözleşme bedelinde bir fark yaratmadığı görülmektedir. Benzer şekilde, Elhag vd. [7] ihale öncesi bedel tahminlemesinde, ihale yöntemlerinin etkili olduğunu söylemektedir.

Sonuç olarak, 2007-2017 yılları arasında 4734 sayılı kanun kapsamında gerçekleştirilen yapım işi kamu alım istatistiklerinin analiz edilmesiyle bulunan sonuçların literatür ile uyumlu olduğu görülmektedir.

\section{SONUÇ}

Bu çalışmada, 2007-2017 yılları arasında 4734 sayılı kanun kapsamında gerçekleştirilen yapım işleri sözleşme bedellerine ait veriler ihale usulü, ihale eşik bedel durumu ve sözleşme türüne göre; SB/YM oranları ihale usullerine göre tablolar halinde derlenmiş ve mevcut durum ortaya konmuştur. Yapılan çalışma, idarelerce gerçekleştirilen yapım işi ihalelerinde 4734 sayılı kanunda belirtilen açık, belli istekliler ve pazarlık usulü ihale usullerinin seçiminin teklif edilen en uygun bedel bir başka deyişle sözleşme bedeli üzerinde etkisi olduğunu göstermektedir. Bunun yanında, ihale sonucunda 4735 sayılı kanuna göre imzalanacak sözleşmenin birim fiyat, anahtar teslimi götürü bedel veya karma sözleşme olmasının ihaleye katılanların teklif bedellerini yani sözleşme bedelini etkilediği tespit edilmiştir. Bu çalışmanın sonuçlarının, idarelere en uygun bedelle iş yaptırmak ve dolayısıyla kamu kaynaklarını etkin bir şekilde kullanmak için dikkat etmeleri gereken hususlar konusunda yardımcı olacağı düşünülmektedir. 


\section{Kaynaklar}

[1] Birgönül, M. Talat, İrem Dikmen. "İnşaat projelerinin risk yönetimi." İMO Teknik Dergi 7.4 (1996): 1305-1326.

[2] Aksoy, M., Yapim İşi Kamu Alimlarinda Yaklaşik Maliyet Belirleme Usulünün Sözleşme Bedeli Ve Etkin Kaynak Kullanimina Etkisi, Kirikkale Üniversitesi Sosyal Bilimler Dergisi, 5, 1, 65-88, 2015.

[3] Gencer, H., Yaklaşık Maliyet Hesaplama Esasları, Uygulamada Karşılaşılan Sorunlar ve Çözüm Önerileri, Uluslararası Katılımlı 7. İnşaat Yönetimi Kongresi, Samsun, 2017.

[4] Kanıt, R., Baykan, U.N., Bina Yaklaşık Maliyetinin Çoklu Doğrusal Regresyon ile Belirlenmesi, Politeknik Dergisi, 7, 4, 359-367, 2004.

[5] Uğur, L.D., Baykan, U.N, Korkmaz, S., Yığma Konutların Maliyet Tahmininde Yapay Sinir Ağlarının (YSA) Kullanılması, 6. İnşaat Yönetim Kongresi, Bursa, 2011.

[6] Gülçiçek, Ü., Yapı Parametrelerinin Değişimi ile Yaklaşık Kaba İnşaat Maliyet Tahmini, Yüksek Lisans Tezi, Sakarya Üniversitesi Fen Bilimleri Enstitüsü, 2011.

[7] Elhag, T.M.S., Boussabaine, A.H., Ballal, T.M.A., Critical Determinants of Construction Tendering Costs: Quantity Surveyors' Standpoint, International Journal of Project Management, 23, 538-545, 2005.

[8] Skitmore, R.M., Ng, S.T., Forecast Models For Actual Construction Time and Cost, Building and Environment, 38, 1075-1083, 2003.

[9] Drew, D., Skitmore, M., Po Lo, H., The Effect Of Client and Type and Size Of Construction Work on a Contractor's Bidding Strategy, Building and Environment, 36, 393-406, 2001

[10] Skitmore, R.M., Early Stage Construction Price Forecasting: A Review of Performance, Surveyors Publication, London, 1991.

[11] Kamu İhale Kurumu, Kamu Alımları İzleme Raporu, Kurumsal Gelişim ve Araştırma Dairesi Başkanlığı, Ankara, 2007-2017.

[12] Kuş, C., Keskin, İ., Levene ve Bartlett Testleri Üzerine Bir İnceleme, Selçuk Üniversitesi Ziraat Fakültesi Dergisi, 22, 44, 78-83, 2008.

[13] Özdamar, K., Paket Programlar ile İstatistiksel Veri Analizi, 9. Baskı, Nisan Kitabevi, Ankara, 2013.

[14] Er, F., Sönmez, H., Üniversite Öğrencilerinde Mükemmeliyetçilik: Anadolu Üniversitesi Örneği, Akü Fen Bilimleri Dergisi, 11-16, 2009.

[15] Karagöz, Y., Nonparametrik Tekniklerin Güç Ve Etkinlikleri', Elektronik Sosyal Bilimler Dergisi, 9, 33, 18-40, 2010.

[16] Calis, G., Kuru, M., Mouawad, J., To Participate Or Not To Participate ? Selecting the Right Participant Profile for Thermal and Visual Comfort Studies, Symposium on Simulation for Architecture and Urban Design (SIMAUD), Delft, The Netherlands, 139-143, 2018. 
[17] İslatince, N., In Turkey and Participation Banks Deposit Banks (2010 -2017) Period Comparison with the Kruskal-Wallis Test and The All Pairwise Comparison Methods Of Financial Performance Differences, Journal Of Current Researches On Social Sciences, 8, 4, 255-262, 2018.

[18] Özcan, B., Sever, S., Sosyo- Demografik Değişkenler Açısından Alkol Kullanımı Ve Çeşitli Kriterlere Göre Analizi, Bilecik Şeyh Edebali Üniversitesi Sosyal Bilimler Enstitüsü Dergisi, 2, 1, 261-276, 2017.

[19] Zengin, N., Yıldız, Z., Sel, A., Katilim Bankalarinin Dağittiği Aylik Kâr Payi Oranlarinin Karşilaştirmali Analizi: (2010-2017), C.Ü. İktisadi Ve İdari Bilimler Dergisi, 19, 2, 555-565, 2018.

[20] Özbek, C.Y., Türkiye'de Bankalarda Lisansüstü Eğitime Sahip Yönetim Kurulu Üyelerinin Bankalarin Kârliliklari Üzerindeki Etkisi: Borsa İstanbul Bankalar Ve Özel Finans Kurumlari Sektörü Örneği, Muhasebe Ve Vergi Uygulamaları Dergisi, 12, 1, 147-166, 2019.

[21] Doymuş, K., Non-Parametrik Testler, K.K.E.F İlköğretim Bölümü, Ders Notu. Erişim: https://Kemaldoymus.Files.Wordpress.Com/2009/12/Non-Parametrik-Testler1.Ppt., 2009.

[22] Bal, A. P., Doğanay, A., İlköğretim Beşinci Sınıf Öğrencilerinin Matematik Dersinde Yapılandırmacı Öğrenme Ortamına Bakış Açıları, Ç.Ü. Sosyal Bilimler Enstitüsü Dergisi, 18, 2, 156-171, 2009.

[23] Çalış, G., Becerik-Gerber, B., Göktepe, A.B., Li, S., Li, N., Analysis of the Variability Of RSSI Values For Active RFID-Based Indoor Applications, Turkish Journal of Engineering and Environmental Sciences, 37, 2, 186-210, 2013.

[24] Yiğit, E., Gamgam, H., Homojen Olmayan Varyans Varsayimi Altinda Ortalamalarin Eşitliği İçin Bazi Test İstatistikleri Ve Karşilaştirmalari, Anadolu Üniversitesi Bilim Ve Teknoloji Dergisi -B Teorik Bilimler, 1, 1, 57-71, 2011.

[25] Taysi, M.R., Çelik, Ş., Homojen Olmayan Varyans Varsayımı Altında Ortalamaların Eşitliği İçin Brown-Forsythe ve Welch İstatistiklerinin Misır Verimi Örneğine Uygulanmas1, Frrat Üniv. Fen Bilimleri Dergisi, 30, 1, 23-27, 2018.

[26] McLaren, B. M., Van Gog, T., Ganoe, C., Karabinos, M., Yaron, D., The Efficiency Of Worked Examples Compared To Erroneous Examples, Tutored Problem Solving, And Problem Solving In Computer-Based Learning Environments, Computers In Human Behavior. Elsevier Ltd, 55, 87-99, 2016.

[27] Calis, G., Kuru, M., Statistical Significance of Gender and Age on Thermal Comfort : A Case Study In Turkey, Proceedings of the Institution of Civil Engineers, Engineering Sustainability, 172, 1, 40-51, 2019. 